\title{
ВПЛИВ РН НА ЗВОРОТНЬООСМОТИЧНЕ ВИЛУЧЕННЯ ХРОМАТ-АНІОНІВ ЗІ СТІЧНИХ ВОД ГАЛЬВАНІЧНИХ ВИРОБНИЦТВ
}

\author{
К.С. Сенькова, М. Д. Гомеля \\ Національний технічний університет Украӥни \\ «Київський політехнічний інститут ім. Ігоря Сікорського» \\ пр. Перемоги, 37, Київ-56, 03056, Україна \\ e-mail: cenka96@ukr.net
}

На сьогодні проблема забруднення природних водойм важкими металами надзвичайно гостро постає як перед Україною, так і перед усім світом. Незважаючи на значні наукові та технічні досягнення в даній сфері проблема залишається актуальною та потребує подальшого дослідження.

Значний вклад в забруднення навколишнього середовища роблять підприємства що мають у своєму складі цехи з нанесення гальванічного покриття. До 90-95 \% води в гальванічному виробництві використовується на промивні операції, причому питома витрата води залежить

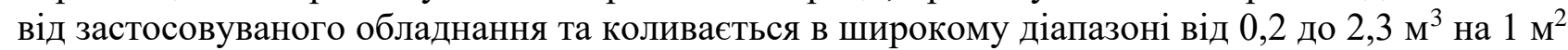
оброблюваної поверхні [1]. Стоки таких підприємств містять катіони важких металів, аніони кислот, хромат-аніони та інші забруднювачі. Проблема очистки стічних вод гальванічних виробництв ускладнюється тим, що розділяти такі стоки надзвичайно складно та економічно невигідно.

Скидання стоків таких підприємств без очищення призводить до завдання значної шкоди як навколишньому середовищу так і людині.

Аналіз літературних джерел показує, що на сьогодні розроблено значну кількість методів вилучення хромат-аніонів зі стічних вод що включають: сорбцію $[2,3,4]$, біохімічні методи [5], реагентні методи [6], електрокоагуляцію [7], іонний обмін [8, 9].

Незважаючи на велику кількість досліджень, присвячених проблемі вилучення хроматаніонів зі стічних вод гальванічних виробництв мало уваги приділяється саме дослідженню та підвищенню ефективності мембранних методів очищення.

Метою цієї роботи було дослідження процесу зворотньоосмотичного вилучення хроматаніонів, впливу характеристик середовища на ефективність процесу вилучення.

Зворотньоосматичне вилучення хромат-аніонів проводилось при використанні розчинів біхромату калію об'ємом 10 дм $^{3}$ з концентрацією шестивалентного хрому в межах від 30 мг/дм ${ }^{3}$ до 45 мг/дм ${ }^{3}$ у дистильованій воді. Фільтрування вищезазначених розчинів проводилось в установці з мембраною низького тиску Filmtec TW 30-1812-50. Для перевірки впливу $\mathrm{pH}$ середовища на процес вилучення хромат-аніонів 3 водних розчинів використовувались модельні розчини біхромату калію в дистильованій воді з концентраціями шестивалентного хрому 33 мг/дм³ $(\mathrm{pH}=5,051)$ (Рис. 3), 30,94 мг/дм ${ }^{3}(\mathrm{pH}=8)$ (рис. 4) та 44,92 мг/дм ${ }^{3}(\mathrm{pH}=10)$ (рис. 5). 
На рисунку 1 показано що, при концентрації шестивалентного хрому 44,92 мг/дм ${ }^{3}$ та робочому тиску 0,3 МПа не вдається досягти повного його вилучення з розчину. Ступінь вилучення шестивалентного хрому залишався в межах 79,3 - 90,7 \% (рис. 2). При цьому спостерігається зниження селективності мембрани при збільшенні ступеня відбору перміату, що може пояснюватись значним підвищенням концентрації іонів шестивалентного хрому в концентраті.

Продуктивність мембрани залишалась в межах $3-3,4$ дм³ $^{3} / \mathrm{M}^{2} \cdot$ год (рис. 2). В останній пробі спостерігалось зниження продуктивності до $\sim 3$ дм³ $^{3} \mathrm{M}^{2} \cdot$ год при ступені відбору перміату $\mathrm{A}=$ $95 \%$.

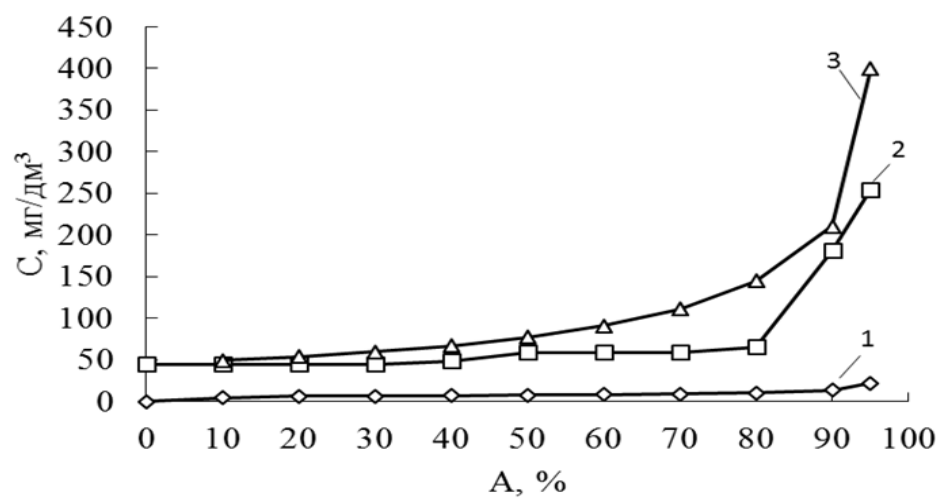

Рисунок 1. Залежність концентрації іонів шестивалентного хрому в перміаті (1), в концентраті (2), теоретично розрахованої в концентраті (3) від ступеня відбору перміату при фільтруванні розчину біхромату калію в дистильованій воді 3 концентрацією шестивалентного хрому 44,92 мг/дм ${ }^{3}(\mathrm{P}=0,3 \mathrm{MПа)} \mathrm{через} \mathrm{зворотньоосмотичну} \mathrm{мембрану}$ низького тиску Filmtec TW 30-1812-50

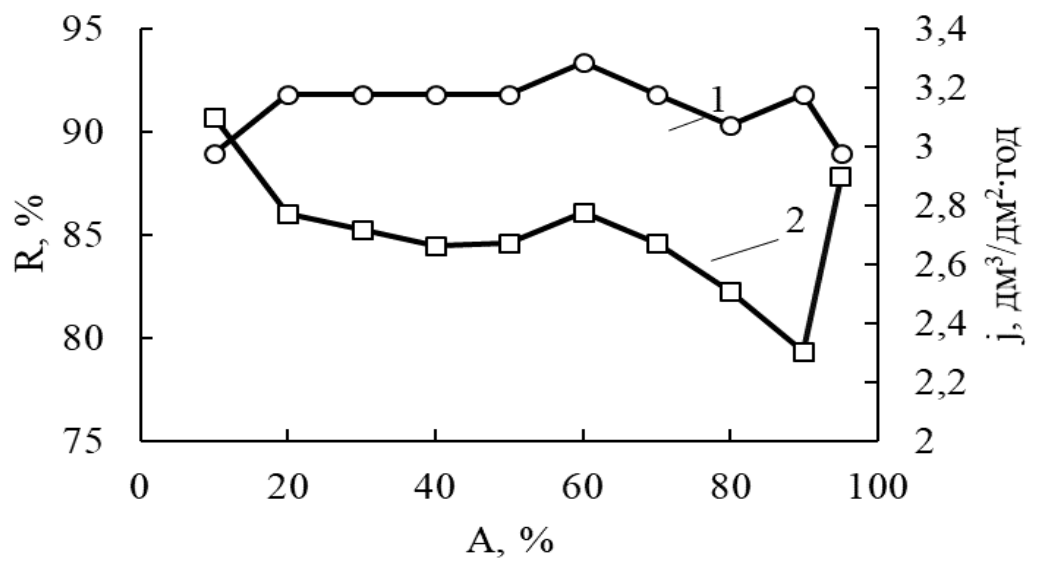

Рисунок 2. Залежність продуктивності (1) мембрани низького тиску Filmtec TW 301812-50 та її селективності (2) по іонах шестивалентного хрому від ступеня відбору перміату при фільтруванні розчину біхромату калію в дистильованій воді 3 концентрацією шестивалентного хрому 44,92 мг/дм ${ }^{3}(\mathrm{P}=0,3$ МПа)

Дослідження ефективності вилучення хромат-аніонів за різного $\mathrm{pH}$ середовища показують, що при підвищенні рН селективність мембрани за хромат-аніонами збільшується. Так за $\mathrm{pH}=$ 
5,051 селективність мембрани знаходилась в межах 90,6 - 93,7 \%, за $\mathrm{pH}=8$ - в межах 89,3 $99,5 \%$ та за $\mathrm{pH}=10$ - в межах $91,1-99,8 \%$ (рис. 3).

Отримані результати можуть пояснюватись тим, що в лужних розчинах при $\mathrm{pH}>6$ хромовий ангідрид $\mathrm{CrO}_{3}$ утворює хромат-іон $\mathrm{CrO}_{4}^{2-}$, в інтервалі $\mathrm{pH}$ від 2 до 6 в рівновазі існують іон $\mathrm{HCrO}_{4}^{-}$та біхромат-іон $\mathrm{Cr}_{2} \mathrm{O}_{7}^{2-}$, а за $\mathrm{pH}$ нижче 1 переважно існують молекули $\mathrm{H}_{2} \mathrm{CrO}_{4}$. При цьому, на процес вилучення впливає різниця в радіусах хромат- і біхромат-іонів. Радіус біхромат іону дорівнює 3,40433 , та є постійним для будь якого біхромату [10]. Радіус хромат іону дорівнює 5,40926 [11]. Отже, за $\mathrm{pH}=5,051$ в розчині переважно існують біхроматіони $\mathrm{Cr}_{2} \mathrm{O}_{7}{ }^{2-}$ які мають менший радіус, а при $\mathrm{pH}>6$ ці іони переходять у хромат-іони $\mathrm{CrO}_{4}{ }^{2-}$, що мають більший радіус. Це також пояснює те, що збільшення рН від 8 до 10 майже не впливає на ступінь вилучення хромат-аніонів.

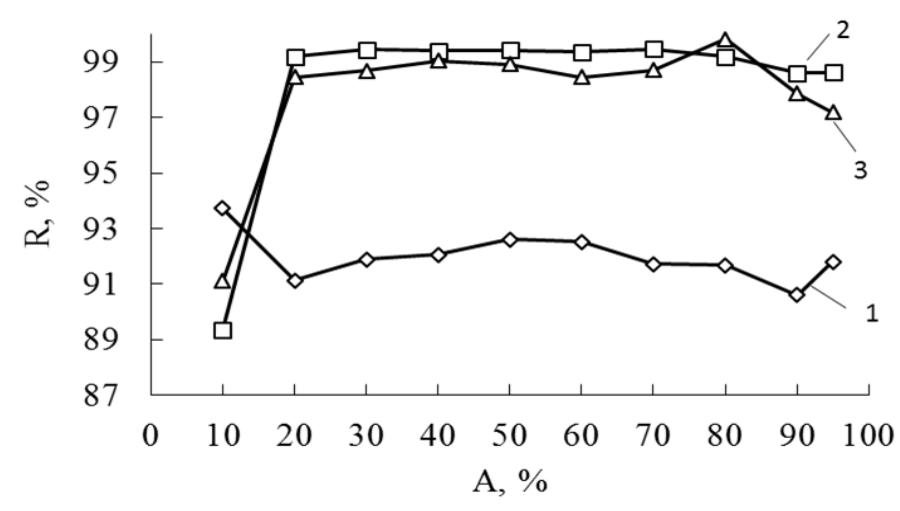

Рисунок 3. Залежність селективності мембрани низького тиску Filmtec TW 30-181250 по іонах шестивалентного хрому від ступеня відбору перміату при фільтруванні розчину біхромату калію в дистильованій воді з концентрацією шестивалентного хрому 30-45 мг/дм та $^{3} \mathrm{pH}=5,051$ (1), $\mathrm{pH}=8$ (2) та $\mathrm{pH}=10,45$ (3) $(\mathrm{P}=0,3$ МПа)

Зміна $\mathrm{pH}$ модельних розчинів не впливала на продуктивність зворотньоосмотичної мембрани (рис. 4).

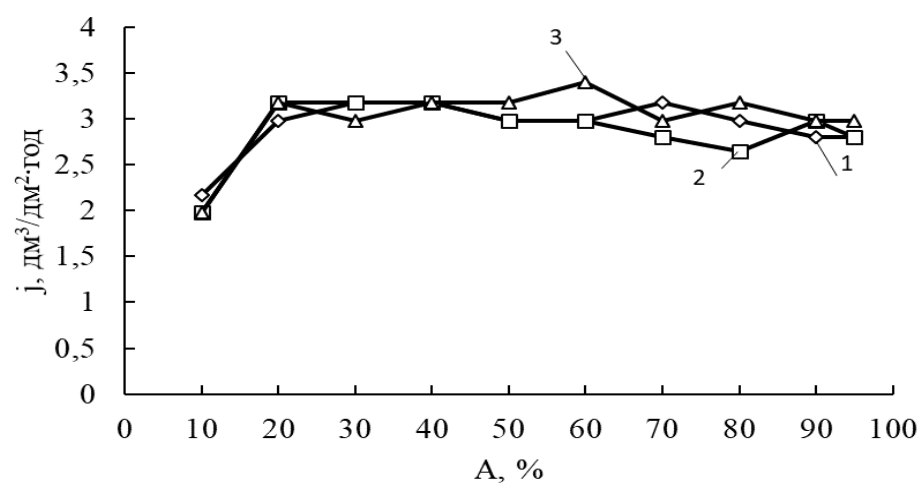

Рисунок 4. Залежність продуктивності (1) мембрани низького тиску Filmtec TW 301812-50 по іонах шестивалентного хрому від ступеня відбору перміату при фільтруванні розчину біхромату калію в дистильованій воді з концентрацією шестивалентного хрому 30-45 мг/дм ${ }^{3}$ та $\mathrm{pH}=5,051$ (1), pH = 8 (2) та $\mathrm{pH}=10,45$ (3) $(\mathrm{P}=0,3$ МПа) 
В роботі показано, що на вилучення хромат - аніонів з водних розчинів при застосуванні зворотньоосмотичної мембрани Filmtec TW 30-1812-5 значною мірою впливає pH середовища: при підвищенні $\mathrm{pH}$ середовища селективність мембрани за хромат-аніонами збільшується.

\section{Література:}

1. Виноградов С.С. Организация гальванического производства. Оборудование, расчет производства, нормирование. / С.С. Виноградов. Под ред. проф. В.Н. Кудрявцева. Изд.2-е, перераб. и доп. - М.: «Глобус», 2005. - 256 с.

2. О.В. Новоселецкая, Т.Н. Боковикова, Н.К. Артемьева, М.Л. Абдуллаева, Л.А. Марченко. Экологически чистый способ очистки от хромат-анионов сточных вод. Физическая культура, спорт - наука и практика. 2008. №1.

3. С. И. Печенюк. Исследование сорбционных свойств аморфных оксигидроксидов металлов по отношению к анионам. Вестник Кольского научного центра РАН. 2013. №3 (14).

4. М.В. Баранова, Л.Р. Шарифуллина. Исследование сорбционной активности углеродных материалов к ионам хрома (VI). Успехи в химии и химической технологии. 2017. №13 (194).

5. Л.И. Иваненко, А.М. Новикова. Восстановление $\mathrm{Cr}(6+)$ культурой pseudomonas mendoscina в лабораторном биореакторе. Вода и экология: проблемы и решения. 2018. №1 (73).

6. М.Г. Ахмадиев, Ф.Ф. Шакиров, Л.М. Назипова, Б.М. Ахмадиев, И.Г. Шайхиев. Моделирование процесса восстановления шестивалентного хрома в сточных водах. Вестник Казанского технологического университета. 2014. №8.

7. Т.И. Халтурина, О.В. Чурбакова, А.Г. Бобрик. Интенсификация процессов очистки сточных вод гальванического производства предприятий машиностроительного профиля. Вестник ИрГТУ. 2016. №4 (111).

8. М.Д. Гомеля, І.С. Сагайдак, В.М Радовенчик. Визначення оптимальних умов очистки промивних вод гальванічних виробництв за допомогою аніоніту АВ-17-8 від хроматів. Экотехнологии и ресурсосбережение. №5 1997, С. 54-56.

9. М.Д. Гомеля, І.С. Сагайдак, В.М. Радовенчик. Дослідження процесів регенерації аніонітів від хромат-аніонів. Экотехнологии и ресурсосбережение. №4 1997 С. 56-59

10. О.Н. Груба, А.Г. Рябухин. Кристаллохимия дихроматов (VI) щелочных металлов // Вестник ЮУрГУ. Серия: Химия. 2009. №23 (156).

11. О.Н. Груба, А.Г. Рябухин. Структурные характеристики хроматов (VI) 3d-элементов // Вестник ЮУрГУ. Серия: Химия. 2010. №11 (187). 